\title{
From modernization to deterritorialization: dynamics and dilemmas of agricultural work in the Cerrado of Piauí, Brazil
}

\author{
Antonio Joaquim da Silva \\ Instituto Federal de Educação, Ciência e Tecnologia do Piauí/ Campus \\ Teresina Central - Teresina - PI - Brasil \\ ORCID: https://orcid.org/0000-0002-9484-8963 \\ Maria do Socorro Lira Monteiro \\ Universidade Federal do Piauí - Teresina - PI - Brasil \\ ORCID: http://orcid.org/0000-0001-5369-4980 \\ Eriosvaldo Lima Barbosa \\ Fundação Getúlio Vargas - Rio de Janeiro - RJ - Brasil \\ ORCID: http://orcid.org/0000-0002-6540-460X
}

\begin{abstract}
The agribusiness has manifested itself as one of the main mechanisms of deterritorialization of the cultural identity of the family farmer of Piauiense Cerrado, conformed in the modernization, in the principles of scientific agronomy and administrative management procedures, aiming at large-scale production, mainly soybeans, and the conquest of markets, has interfered with the landscape, work, land use, in habits and socio-cultural practices, reaching the ecosystem and generating social conflicts, such as land concentration, setting a serious socio-environmental crisis. Thus, it is necessary to question the context of occupation of the Cerrado of Uruçuí by agribusiness and its repercussions on the continuity of family agriculture. In this sense, it is pointed out that this article intends to analyze the deterritorialization caused by the agribusiness grain in the family farming of Uruçuí. This descriptive/explanatory study was based on the dialectical and ethnogeographic methods, which were subsidized by bibliographical, documentary and survey research, as well as by semistructured forms applied among 254 family farmers of Uruçuí. It was concluded that the process of deterritorialization in Uruçuí, caused by the diffusion of agribusiness, was mainly confirmed by the subordination of family labor to temporary work on large agricultural properties, since it was devalued, with a low level of specialization and low pay; in reducing mutual aid relations between rural communities; in changes in ways of life; and the eminent dependence of family farmers on the idyllic application of chemical inputs in crops.
\end{abstract}

Palavras-chave: Family agriculture. Agribusiness. Cerrado. Social and environmental impacts. 


\section{Da modernização à desterritorialização: dinâmicas e dilemas do trabalho agrícola no cerrado do Piauí, Brasil}

\section{Resumo}

O agronegócio tem se manifestado como um dos principais mecanismos de desterritorialização da identidade cultural do agricultor familiar do cerrado piauiense, haja vista que a recente ocupação empresarial do município de Uruçuí, conformada na modernização, nos princípios da agronomia científica e nos procedimentos de gestão administrativa, visando à produção em larga escala, sobretudo, soja, e a conquista de mercados, tem interferido na paisagem, no trabalho, no uso da terra, nos costumes, nos hábitos e nas práticas socioculturais, atingindo o ecossistema e gerando conflitos sociais, como a concentração fundiária, configurando uma grave crise socioambiental. Assim, faz-se necessário questionar o contexto de ocupação do cerrado uruçuiense pelo agronegócio e suas repercussões sobre a continuidade da agricultura familiar. Nesse sentido, salienta-se que este artigo pretende analisar a desterritorialização provocada pelo agronegócio granífero na agricultura familiar de Uruçuí. Este estudo descritivo/explicativo se embasou nos métodos dialético e etnogeográfico, os quais foram subsidiados por pesquisas bibliográfica, documental e levantamento, como também por formulários semiestruturados aplicados entre 254 agricultores familiares de Uruçuí. Concluiu-se que o processo de desterritorialização em Uruçuí, ocasionado pela difusão do agronegócio granífero, confirmou-se, mormente, na subordinação da mão de obra familiar ao trabalho temporário nas grandes propriedades agrícolas, pois a mesma era desvalorizada, apresentando baixo nível de especialização e reduzida remuneração salarial; na diminuição das relações de ajuda mútua entre as comunidades rurais; em mudanças nos modos de vida; e na eminente dependência dos agricultores familiares à aplicação idílica de insumos químicos nas lavouras.

Palavras-chave: Agricultura familiar. Agronegócio. Cerrado. Impactos socioambientais.

\section{De la modernización a la desterritorialización: dinámicas y dilemas del trabajo agrícola en el cerrado del Piauí, Brasil}

\section{Resumen}

El agronegocio se ha manifestado como uno de los principales mecanismos de desterritorialización de la identidad cultural del agricultor familiar del cerrado piauiense, en vista que la reciente ocupación empresarial del municipio de Uruçuí, conformada en la modernización, en los principios de la agronomía científica y en los procedimientos de gestión administrativa, con el objetivo de producir a gran escala, sobretodo la soja, y la conquista de mercados, ha interferido en el paisaje, el trabajo, el uso de la tierra, las costumbres, los hábitos y las prácticas socioculturales, alcanzando el ecosistema y generando conflictos sociales, como la concentración agraria, configurando una grave crisis social y ambiental. Así, se hace necesario cuestionar el contexto de ocupación del cerrado uruçuiense por el agronegocio y sus repercusiones sobre la continuidad de la agricultura familiar. En ese sentido, se subraya que este artículo pretende analizar la desterritorialización provocada por el agronegocio granífero en la agricultura familiar de Uruçuí. Este estudio descriptivo/explicativo se basó en los métodos dialéctico y etnogeográfico, los cuales fueron subsidiados por investigaciones bibliográfica, documental y levantamiento, así como por formularios semiestructurados aplicados entre 254 agricultores familiares de Uruçuí. Se concluyó que el proceso de desterritorialización en Uruçuí, ocasionado por la difusión del agronegocio granífero, se confirmó, principalmente, en la subordinación de la mano de obra familiar al trabajo temporal en las grandes propiedades agrícolas, pues la misma era devaluada, presentando bajo nivel de especialización y una remuneración salarial reducida; en la disminución de las relaciones de ayuda mutua entre las comunidades rurales; en cambios en los modos de vida; y en la 
eminente dependencia de los agricultores familiares a la aplicación idílica de insumos químicos en las labranzas.

Palabras-clave: Agricultura familiar. Agronegocio. Cerrado. Impactos socioambientales.

\section{Introduction}

It is, according to Silva, Monteiro \& Barbosa (2017a), that the historical formation of the Brazilian economy was based on the agricultural activity, when the geo-environmental conditions were favorable, such as climates, topographies, grounds and hydrography, and political actions, like territorial defense and supply for the domestic and global markets.

Nevertheless, according to Zuquim (2007), from the colonization, the great rural enterprise predominated on the small property, which resulted in the introduction, diffusion and consolidation of the capitalist tillage, causing socioeconomics disparities between the urban and rural spaces and the increase of the environmental impacts.

This conformation highlights that the large-scale monoculture agriculture, which logically takes the production or culture of only one agricultural specialty, intensified itself in an itinerant way, dependent on inputs and modern technologies and on the foreign market, and according to Prado Junior (2008), the monoculture agriculture evolved without internalizing the dimensions of the sustainability, regarding the deep alterations in the natural environments of the coast towards the interior and in the sociocultural conditions of the local populations.

According to Zuquim (2007), in the second half of the century XX the government policy of urbane/industrial development and of agricultural modernization privileged the public investments in sectors of industrial expansion of the cities and in the productivist sector of the rural areas. Thus, showing up that to modify the economically backward situation of the Brazilian rural zone, it was necessary to modernize the agriculture, which stimulated the monoculture, the technification and the mechanization, which were understood as modern and productive agriculture models.

However, according to Barbosa (2009), the insertion of Brazil in the process of modernization of the agriculture, occurred in a slow and gradual way, with the objective to keep on satisfying the demands of the internal and extern markets, which required the urgent incorporation of new geographical spaces with natural characteristics and favorable infrastructures so that they could become productive and profitable.

In this perspective, the politics of national integration stimulated by the military governments (1964-1985), favored the occupation of territories with productive potential in the country, among which there is outstanding the Cerrado biome, which consists of a tropical savanna with presence of bigger biodiversity of the world, and in the second biggest vegetable formation of Brazil on account of concentrating a third of the fauna and flora (FALEIRO et al., 2008; SILVA, MONTEIRO \& BARBOSA, 2015a).

Furthermore, for Andrade (2011), the politician of national integration implemented during the 1960 years and 1970, Saint Francisco made possible the colonization of territories with low demographic density, like the Northeast region, through the use of the river for the dams construction for the production of 
hydroelectric energy and opening of new agricultural frontiers, and of the construction of Brasilia, capital of the country, between the 1955 years and 1960, besides the roads construction. Being so, farmers of several areas of Brazil, mainly businessmen of the South and South-east, started to produce grains in the new territories, especially soy, aiming to pay attention to the interests and demands of the international financial market.

In view of this configuration, Monteiro \& Aguiar (2006) point out that nevertheless the occupation and use of the cerrado from Piauí to have begun in the decade of 1970, through incentives of the Investment fund of the Northeast (FINOR-farming) and of the Partial Investment fund (FISET), only from the decade of 1990, took place to intensification of the installation of great producing undertakings of grains, in individual, soy, attracted, specifically, by the low price of the lands, by the exhaustion of arable grounds in other regions of ancient occupation, by the characteristics geo-environmental favorable (climate, ground, relief and hydrography), by the proximity of the consumer markets and by the made easy resources of the federal and state governments.

Consequently, in accordance with the Brazilian Institute of Geography and Statistic (IBGE), between 1990 and 2018, the area planted in the Piauí, particularly in areas of Cerrado, with strong aspect joint biotechnologies, the monoculture of the soy, the importance in the market of the commodities, grew of 1.560 hectares for 711.123 hectares, respectively, corresponding to an increase of 445,8 times to planted area (IBGE, 2020).

However, because of this performance, Silva (2016) secure that the expansion of the cultivation of tillage temporary with business production standards, enables reflections on the impacts socio environmental resulting from the consolidation of the agribusiness in so far as this productive sector privileges the monoculture, the use of technological innovations (chemical inputs, mechanization and improved seeds), little labor and low salaries, besides the maintenance of great rural properties.

On account of this scenery, Silva, Monteiro \& Silva (2015a) they understand the agribusiness as a project sociopolitical organized around agrarian elites that defend the active participation of the State in the concession and protection of benesses of a social segment that it produces for the market of commodities, articulated to the demands of the international financial capital.

Then, according to these authors, the agribusiness sector represents itself as the phenomenon responsible for socio changes that directly affect the identities, the temporalities, habits and strategies of social resistance and cost of family farmer, which consists in a social actor based in the virtues of society farmer (SILVA, MONTEIRO \& BARBOSA, 2016), whose authentic legitimizes itself as a special feature that does not exhaust compared to the roughness of reproduction of capital in the countryside (SILVA, MONTEIRO \& BARBOSA, 2017b).

The agribusiness sets up new fact the sceneries, the relations of work, the consumption and the sociabilidades, function of the exchanges that pours, suffers influences, modify the local and regional conditions of existence, inclusive there alter the processes of reproduction socioeconomic of the populations existent-daily pay to his installation, like the traditional communities, particularly, natives, fugitive 
Negro slaves, messengers, agriextrativists and familiar farmers (SILVA, MONTEIRO \& BARBOSA, 2017C).

Based on this construction, it is understood that the agribusiness manifests itself as one of the main mechanisms of deterritorialization of cultural identity in the Cerrado of Piauí, reaching directly to land, the people and the animals; the resources and customs; the relations of reciprocity and the daily life; the habits and practices; socio-cultural projects and the horizons for the future of the populations of the towns.

On basis of this problem, it was elected Uruçuí as object of the investigation on account of having been a pioneer in installing graniferous undertakings (producing undertakings of grains) in the state of the Piauí, making available infrastructure for the agribusiness and leading the ranking of municipalitys with the best GNP per capita - performance resulting from the Added Value (VAIN) of the farming (CEPRO, 2015).

It is noteworthy that Uruçuí is situated in the south-west geographical state, in which stands out for being the area of highest production in the state (CEPRO, 2014). Consequently, the recent one to occupation of the Cerrado of Uruçuí for the production in wide scale, has been turning in intense process of deterritorialization identity, in so far as the agricultural modernization developed in the areas of plated (spaces that present flat topography or easy wavy and viable to the mechanization) has interfered in the landscape, work, land use and the sociability, has even generated social conflicts, such as the concentration of land, which has reflected rural exodus (SILVA, MONTEIRO \& BARBOSA, 2017d).

In this perspective, it should be emphasized that the problem of this research focuses on understanding the implications of the occupation of cerrado uruçuiense for the graniferous agribusiness of the familiar agriculture of traditional cultures of local and regional consumption. In this way, it is punctuated that this article aims to analyze the deterritorialization caused by the agribusiness in the familiar agriculture of Uruçuí. For this purpose, the article is structured in six sections, besides this introduction. The second section presents the methodology of the study; the third section examines the origins of the agribusiness, the dissemination in the country, especially in the Central Plateau, owing to the region is a pioneer in sheltering the business agriculture in the Brazilian Cerrado; the fourth section discusses the state-owned participation in financing the incorporation of Uruçuí in the logic of installation/consolidation of the grain agribusiness; the fifth section socializes the results of the inquiry; and the sixth section presents the final considerations of the study.

\section{Methodology}

It is noted that the research methodology is underwrote us dialectical and ethno geographic methods, consider them relevant to the representativeness and scientific research. Furthermore, it points out that the dialectic concludes that facts and ideas are constantly changing and, therefore, reconciles opposing thoughts (SPOSITO, 2004). Already ethno geography makes a summary of the representations that a society is the geographic area, such as the use of natural resources, the relations of life and socio-cultural processes (CLAVAL, 2002). 
In terms of technical procedures, they were based on bibliographic researches (in books and scientific magazines), documentary (in sites of government institutions that treat the theme) and lifting, in which it made use of data collections in field, through the forms application between 254 familiar farmers of the rural zone of Uruçuí, selected through statistical probability and on basis of the study of the municipal agrarian structure, carried out by the National Institute of Colonization and Land Reform (INCRA, 2013), which classifies the rural real estate how much the size (dimensions) and the nature of the economical exploration. For his time, the INCRA adopts the fiscal module, which in Uruçuí corresponds to 75 hectares.

Thus, the authors investigated the rural properties in the area does not exceed four fiscal modules, by recognizing that such buildings best portraying the reality of reproduction of family farming in Uruçuí. For the calculation of the sample, we used the Program Sample Size Calculator by Raosolft, by defining the sampling error of $5 \%$ and a confidence level of $95 \%$, which is essential for safety and scientific quality of the research In this way, the universe of 741 rural properties with up to four fiscal modules registered by INCRA, were analyzed 254 family farmers, distributed in rural communities in the municipality. It should be emphasized that the issues raised was on the knowledge and practices of farmers for productive use of the land and the inter-relationships with the sustainability of the cerrado.

\section{Agribusiness in the Brazilian cerrado: the occupation of the Central Plateau}

According to Graziano da Silva (1998), agribusiness derives from agribusiness, expression that has arisen in the United States of America, in the late 1950s, when John Davis and Ray Goldberg, then teachers from Harvard Business School, realized that agriculture, livestock and activities linked to them should not be analyzed separately, there is a view of the interdependence of the three economic sectors. Therefore, For so much, through the concept of the matrix input/product diverted of the neoclassical theory of the production of Wassily Leontief (it allowed to calculate the flow of entry that must take place in order that determined exit flow is obtained, between input and products), they organized those sectors according to the integration of a system agro industrial. Therefore, they defined it like the sum of all the operations wrapped in the processing and in the distribution of the farming inputs, in the practices of cultivation and in the harvest in the farm; and storage, improvement and distribution of the agricultural produce and derivatives.

In Brazil, the materialization of conceptual agribusiness occurred through the Brazilian Association of Agribusiness (ABAG), established in May 1993 to represent the interests of large enterprises support (SILVA, MONTEIRO \& BARBOSA, 2015b). Soon, To Sauer (2008), this conformation means that the definition of agribusiness projects under the foundations of politics and issues relevant to the exploitation of the agricultural economy controlled by a small group of capitalists.

However, for Cano (1998), the introduction of agribusiness date of changes in patterns of agricultural production occurred in the second half of the 20th century when it intensified the internalization of the industry of modern inputs, 
machines and equipment which, consequently, spread the decomposition of the rural complex, which was characterized by the dependence of fluctuations in the external market and by the use of agricultural technology fairly rudimentary in virtually all regions South and Southeast.

In virtue of this panorama, Silva, Monteiro \& Silva (2015) emphasize the II National Development Plan, proposed by the Federal Government, in 1970, as an instrument to play the installation of agribusiness in the country, gathering subsidized mechanisms as a means to maintain the performance of the phase of economic growth pace (miracle).

Among the mechanisms, Silva (2016) show the policies of agricultural credit recommended by the National System of Rural Credit, which grants bank financing by means of working capital limits for long, the Politics of Guarantee of Least Prices, which is characterized for the state-owned intervention in the control of prices in the market to secure the profitability of the rural producer in periods of excess of agricultural production, the commercial opening, the changes in the agrarian structure, the fiscal incentives and the scientific inquiries.

Therefore, it is noted that from the aforementioned decade starts the process of expansion and modernization of the border, understood, according to Martins (2014), as a place of conflict and historical limits, whose conversion of cerrado the imperative of grain production/meat is based on the dynamics of the global market.

It is added, in harmony with Brazil (2014), that the Cerrado biome occupies approximately $24 \%$ of the national territory, in a $2.036 .448 \mathrm{~km}^{2}$ respected total area, including 1.388 local authorities distributed between the Federal area and the states of the Bahia, Goiás, Maranhão, Mato Grosso, Mato Grosso of the South, Minas Gerais, Paraná, Piauí, Sao Paulo and Tocantins.

In addition, scores, in accordance with Peixinho and Scopel (2009), that the agribusiness sorghum, soybean, that decade occupied the southern and southeastern regions, disseminates to the Central Plateau, and then to the Northeast and North, potentiating the practices of new economic agents and deepening social tensions.

Thus, it is noted that before arriving in Uruçuí, agribusiness landed in the cerrado in the Midwest region, attracted by the benefits of the development program of the Cerrados (POLOCENTRO) and the Cooperation Program NipoBrasileira for Agricultural Development of the Cerrado region (PRODECER).

The POLOCENTRO, created in 1975, was intended to enclose areas of the biome to complex Agro (CAls) through benefits (agricultural credit) and benefits (price of land), plus the availability of infrastructure, such as raw materials, seeds, warehouses, machinery, technical assistance and the construction of roads and highways (ALHO, MARTINS, 1995; MATOS \& PESSÔA, 2011).

Already The PRODECER, consisted of an agreement between the Brazilian government and the Japanese, signed in 1974, to colonize and exploit the lands of Cerrado under systems of cooperatives coordinated by the Company for the Promotion Fund (Field) a multinational company run by two holdings, the Brazilian Company of Participation Fund (BASAGRO) and Japan-Brazil Agricultural Development Corporation (JADECO). The first contained $51 \%$ of the shares 
controlled by national capitals, while the second was $49 \%$, whose command was led by foreign capitalists (ALHO, MARTINS, 1995; OLIVEIRA, 2005).

For Alves (2014), such programs were directly responsible for the occupation and modernization of the Central Plateau cerrado, making the soy to main produced culture. This required the dependence of the state on financial capital, the expansion of agro-industries through the establishment of CAls and linking the agricultural economy rationality of the global market.

Register, in accordance with Silva (2016), that the conditions geo environmental of cerrado proved favorable to the installation of corporate farming, since topography, climate and soil, not prevented the introduction of the new modus operandi.

Thus, the increment of mechanization in the cerrado was made possible on the basis of the relief plan and/or gently undulating, the climatic characteristics (light, temperature and rainfall) and the correction of soils (with the use of chemicals in order to decrease the acidity and restore nutrients, such as calcium and magnesium). In addition, the use of improved seed, the control of insects, pests and diseases, and the professionalization of the producer (PEIXINHO \& SCOPEL, 2009; BRANDÃO FILHO, 2009).

In fact, to Peixinho and Scopel (2009), these factors have increased the development of grains in the cerrado, requiring the personification of a modern producer who knows to handle the technical basis of production and incorporating a business rationale. However, this does not mean that all who produce grains in the cerrado are entrepreneurs, but that his dynamic productive is associated with the formation of corporate group capable gives cohesion to the organization of agribusiness.

Based on this context, is understood what the agribusiness settled down in the Central Plateau unleashing an economy in scale, at the same time it disseminated serious social problems, like the concentration of land ownership.

\section{The installation of agribusiness in Uruçuí}

Uruçuí was founded on 23 June 1902, whose title was related to environmental factors, since the lands of the municipality is located in the valley of the river Uruçuí Preto, which belongs to the hydrographic basin of the Parnaíba river, Uruçuí is located in the Cerrado biome, has a land area of $8,452.025 \mathrm{~km}^{2}$ (Figure 1). 
Figure 1 - Illustrative map of the municipality of Uruçuí, Piauí, Brazil

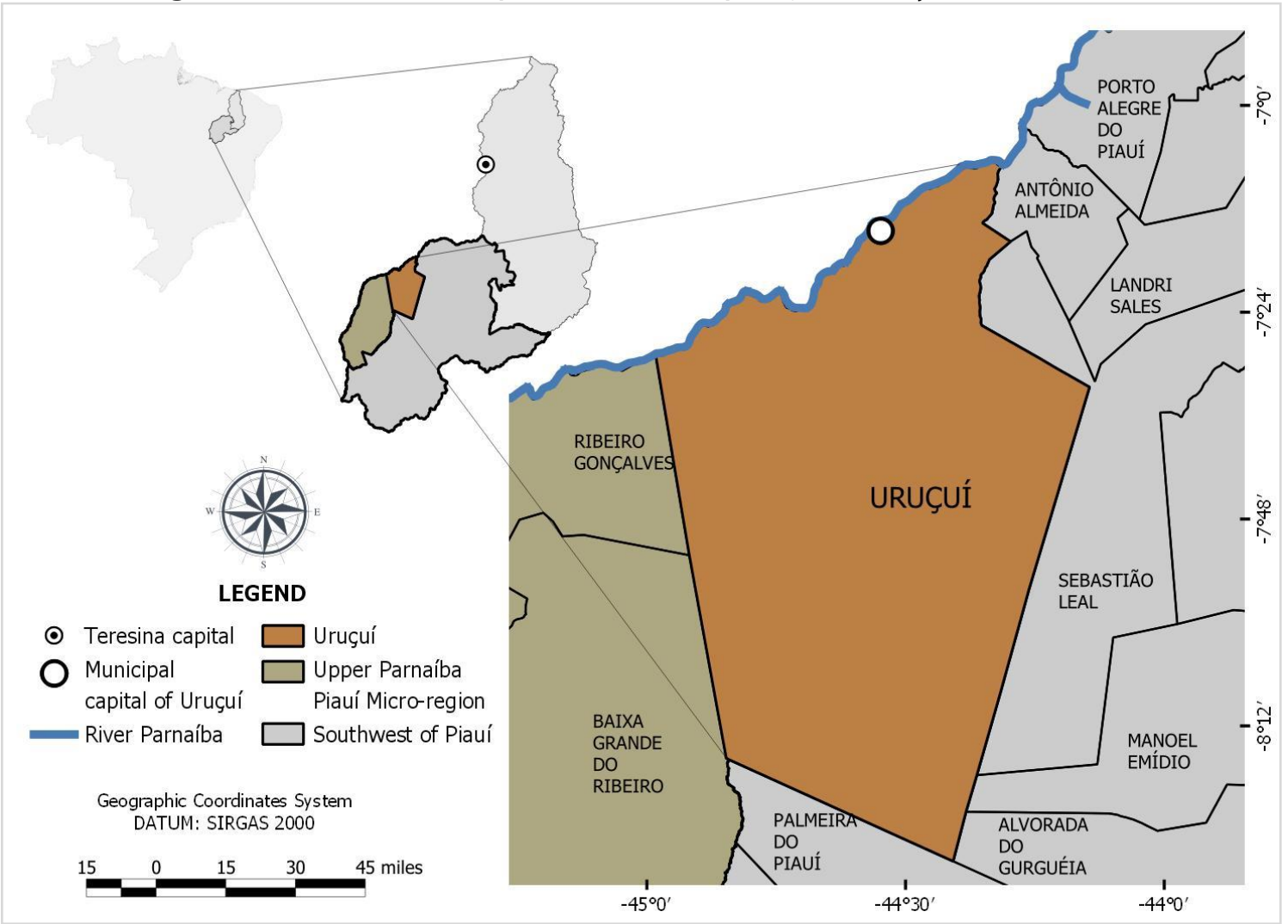

Source: Elaborated by Felipe de Sousa Dantas (2020).

At the regional level, the municipality comprises the high Parnaíba Piauí, Microregion constituent of Mesoregion Southwest Piauiense. According to the IBGE (2010), this year, Uruçuí counts on a population of 20.149 inhabitants, whose space distribution is distinguished in $\mathbf{1 5 . 5 0 6}$ and 4.643 inhabitants in the urban and rural zones, respectively.

It should be emphasized that the establishment of joint ventures graníferos in Piauí does not differ from other states where the agribusiness landed, government policies are decisive for the changes in the socio-spacial areas of planting, harvesting, storage, distribution and marketing, increased from the 1970s, particularly in Uruçuí. From this perspective, for Monteiro and Aguiar (2006), the exploitation of the cerrado uruçuiense began in the 1970s, through grants from the Fund for investment in the Northeast (FINOR-farming) and the Investment Fund Sector (FISET), which ensured incentives and concessions for a small group of rural landowners, considered to be able to develop and disseminate the new agricultural engineering.

However, despite the role played by such programs it should be emphasized that it was only from the years 1990 which occurred the expansion of the installation of large enterprises graniferous, attracted mainly by the low price of land, by the reduction of soil land in regions of old assignment, the conditions geoenvironmental favorable, due to the proximity of the consumer markets and by incentives from federal and state governments (MONTEIRO \& AGUIAR, 2006; ARAÚJO, ARAÚJO, 2007; SILVA, MONTEIRO \& BARBOSA, 2015a). 
Besides to those mentioned above programs, it is also, according to Peixinho \& Scopel (2009), institutionalization of Law no 4,859, dated 27 August 1996, whose purpose was to attract agribusiness companies for the Piauí, where the State undertook to provide tax exemption between 60 and $100 \%$, up to 15 years for the Tax on Circulation of Goods and Rendering of Interstate and Intermunicipal Transportation Services and Communications (ICMS), to be granted to the enterprises graníferos and agribusiness, considered as a priority for the exploration of the cerrados.

Soon, for Monteiro and Aguiar (2006), such institutional arrangements resulted, in other respects, the modernization of agriculture, the installation of industries and agro, in productivity growth, in the formation of a land market and the expansion of the agricultural frontier (via exploitation of speculative land), in other respects, the maintenance of large rural properties, changing the direction of the primary activity, to replace the cultivation farming in intensive.

In addition, adds that in Uruçuí, the withdrawal of the vegetation of the areas of plains to the deployment of plowing a capitalist not only has a big environmental impact, but, above all, committed to territorial identity of the native population, since the chapadas represented for the peasant families places of common use, i.e., the areas of natural reserves where you let the cattle to the advantage of the pasture (at certain times of the year), or served as the place of plant extraction (wood, Or served as the place of plant extraction (wood, fruits and medicinal plants) and hunting of wild animals (ALVES, 2009).

Thus, the plains called the empty land, that is, idle land and not enclosed, which were extensive without ground of native cerrado, essential for the reproduction of sociocultural native population (PEIXINHO \& SCOPEL, 2009).

So, how is the issue, it agrees with the concept of CHELOTTI (2010), that the territorial identity expresses individual subjectivity and collective belonging to the territory, and, then, fundamental to the conformation of rural livelihoods, the habits, customs, of knowledge and social practices.

Therefore it stresses that the new socio-spacial organization Uruçuí reverberated acute dispossession processes, which for Ortega (2012), triggers the formation loss of the symbolic character of the territories.

Such opinion of Ortega track against the analysis of Deleuze and Guattari (2011), that the deterritorialization denotes a line of flight, i.e., assumes a break in which the multiplicities (subjecvations, determinations, dimensions, distances) Socio-spatial change of direction when connecting to unknown or outsiders. Thus, correlate the deterritorialization to climate sociocultural caused by technological innovation resulting from the process of globalisation of the economy.

That said, it is understandable why Silva, Monteiro \& Barbosa (2015a) are emphatic when ensuring that technical systems have become an integral part of the landscape of Uruçuí, expressing new times in the daily life of rural communities (and of the urban population), with this, the sense of time imposed by agribusiness is based on commodity production, that is, a time whose pace is oriented in the logic of capital appreciation. 


\section{Results and Discussion}

The results of the field survey, in the rural properties of Uruçuí city, estimated that $58.7 \%$ of the familie farmers' plantations were cultivated in valleys, characterized by being depressed land and damp and $41.3 \%$ in the Chapadas, who presented topography $\mathrm{tv} / \mathrm{high}$ in relation to the baixões, whose main crops were rice (Oryza sativa), beans (Phaseolus vulgaris L.), maize (Zea mays), cassava (Manihot esculenta) and beans (Phaseolus lunatus L.), produced of traditional form with the use of primitive tools, such as axe, machete, sickle, etc. It is emphasized that the use of tools such as hoes, axes, sickles and machetes was predominant in all family crops, which were incorporated into the various stages of the production process, like cleaning the ground, sow the seeds and reap the harvest. It was discovered that these instruments are linked to the so-called eco-types, technical systems designed by Wolf (1976) as a result of a long process of cultural accumulation, positioning them between the models paleotécnicos (employment of human labor and animal) and neotechnics (anchored in power usage of fossil fuels and improving scientific).

It is Pointed out that the reasons for the predominance of plantations in the areas of valleys were associated to natural conditions such as soil and moisture, but, above all, to the process of occupation of plateaus by graníferos enterprises, once acted both cornering family farmers in these environments, such as those obliging to migrate to the cities.

However, about this situation, Brandão Filho (2009) comments that the expansion of agribusiness in Uruçuí aggravated the agrarian question, causing social instability, in that it intensified the land titling problems, such as possessions, fragmentations, disputed areas, etc., resulting in the expulsion of farmers from the land of collective use (plateaus) and the migration to the baixões and urban areas.

It should be emphasized that in addition to the GM explained, there was a small scale production of tropical fruits, which were often grown on land of dwelling, with the purpose of improving the quality of the food security at the household level. The diversity of these products, and ensure the daily subsistence farmers, contributed to the spread of the multifunctional character of family farming in Uruçuí.

There was also a predominance of family labor in the reproduction of crops because of all analyzed farmers in the empirical research, $60.2 \%$ developed their production practices with family members, while $39.8 \%$ were hiring temporary labor of others. This dependence on hired labor, expressed a resizing process of mutual aid contexts, since historically the practice of joint efforts in Uruçuí functioned as a rule, that is, as a moral order among farmers.

And that the contact of farmers with modern technologies (tractors, combines, mechanical planters, etc.) made to the circumstances of rent and loan with the large rural properties, the borne the costs of development of biotech family. Concerning to the destination of agricultural production, it was identified, according to field data collection in the rural properties, that $91.3 \%$ of family farmers of Uruçuí did not trade their crops, while $8.7 \%$ of workers used to take their crops to the market to be traded. 
This conformation allowed characterizing the logic of agricultural production in the municipality as economy of supply, whose purpose of household production, according to Sahlins (1983), Moraes (2009) and Silva, Araújo \& Barros (2015), would be subject to the partial relations with the market, thus, if it would produce for the exchange, in order to obtain goods they needed and does not produce. However, despite this multifunctionality of Uruçuí, it was verified, by means of field investigation, that the installation of graníferos enterprises in Uruçuí triggered new productive habits which passed to regulate substantively the organization of family farming. Such a configuration is clearly evidenced in the materialization of the consumption of chemical inputs, because, according to field data collection, 254 of the rural properties researched, $67.0 \%$ of farmers incrementavam these compounds in its plantations, $23.0 \%$ used only natural products and $10.0 \%$ desconsideravam such interventions chemical or organic in their crops. This situation of dependence on chemical inputs was made explicit in the testimony of a farmer:

We didn't have this kind of pest on vegetables, we believe it was because of the deforestation in the plateaus. Today, there is a lot of pest in the vegetable, $[\ldots]$ we do the treatment with the same poison $[\ldots] "$.

Consequently, this panorama has confirmed the assertion by Silva (2016), that the agribusiness establishes new realities in landscapes, in the organization of work, in habits and in sociabilidades, through an increase of trade that trigger, interfere, suffer influences, alter the living conditions of local and, especially, modify the processes of reproduction of family farming.

Therefore, it was noticed that in Uruçuí the homogenizing action of agribusiness rationality resulted sobremaneiramente in increased use of chemical inputs in labor land of family farms mainly in the increase of fertilizers and pesticides, with the purpose of increasing land productivity by setting up a process of breaking farmers with traditional practices of land use, and at the same time accentuating the dispossession of identity knowledge of sustainable use of cerrado resources.

Therefore, it was found that the increasing use of chemicals in plantations was mainly related to the integration of family labor in grain sorghum enterprises because of the 254 surveyed farmers, in Uruçuí city, $61.8 \%$ had work experience in large rural property, whose hiring time did not exceed 12 months and occupations not requiring high skills and high wages, given that the totality of farmers who volunteer their workforce for agribusiness, 66.2\% were garrancheiros (roots pickers, branches and stumps), 29.2\% were machinery operators and $4.6 \%$ practiced other crafts in the agriculture business.

This work selectivity framework has adapted the concepts of Bernardes (2009) and Browder, Pedlowski \& Walker (2008), that due to agribusiness use of technological innovations and management practices, reduces the amount of workers, offering, when necessary, temporary services and low cost.

Grounded in this reality, it was understood that the agribusiness consolidation Uruçuí denoted a scenario of uncertainty about the future of family farming because all the farmers ofertavam labor for agribusiness would not think of working on farms but as a necessity, as a farmer explained: 
Today farmers do not want to go back more to hoe because it is hard even for those who're used to earn a salary of them there on the farms [...]. For me, in my dreams, so it was a fumble [...].

Thus, through this conformation, it was understood that in Uruçuí, agribusiness acted to deepen the territorial capital, which included the appropriation of environmental goods and domination and subordination of family farmers.

On the other hand, it inferred that the agribusiness diffusion process in Uruçuí caused substantial environmental impact, which affected the climate (SILVA, 2016), biodiversity, with the intensity of the use of pesticides and their direct impacts on the dynamics of flora and soil resilience (OLÍMPIO \& MONTEIRO, 2007; MORAES \& MONTEIRO, 2007), and the rural population living, especially in the ways of life of rural workers (SILVA, 2016), which sparked the small producers a moral order as the rational use the various potentials of the cerrado, as $92.9 \%$ of householders have expressed some concern about the sustainability of the savannah, as the control deforestation and fires and preservation of plant species estimated use.

Soon, it was noted that this contextualization mirrored the analysis Wanderley (2003), that the family farmer is a social actor's globalized world, so it is not shown as a passive character without resistance in the face of changes in the field imposed by capital. This situation was commented on by an interviewed family farmer who reported:

When we didn't have these large farms here, we didn't suffer from as much drought, as we are suffering today, and we think that the main factor for this drought, lack of water, is the deforestation of the Cerrados, because here it was not like it is now, ten or twenty years ago [...].

Such reality was also criticized by another farmer who stressed that with the entrepreneurial occupation in the Cerrados, the deforestation was intensified and also its reflexes in the ecological balance, as demonstrated in the memory narrative:

[...] Today there are a lot of pests in the vegetable due to deforestation and with the lack of rain, the pest in vegetables has been accelerated a lot, it gives a lot of caterpillar and a certain grasshopper, a beast that eats the leaves of plants and does a lot of damage here in the communities of Uruçuí $[\ldots]$.

In addition to this configuration, it was found that family farmers disagreed with the conversion of plateaus into goods for agribusiness, since the productive rationality disseminated by corporate agriculture interfered in the ecological balance and in the habits of the locations, as one farmer commented: "when we didn't have these large farms here, we didn't suffer from so much drought [...], and we think that the main factor for this drought, lack of water, is the deforestation in the Cerrados, because it wasn't like that before [ ...] ".

Based on the above, it was recognized that the family farmer from Uruçuí resisted the advance of territorialization of agribusiness, and did so precariously combining its traditionalism to innovations and rationality of agribusiness. And that 
territorial identity was a family farmer's defense mechanism not exhausted at the dynamics of the enlarged capital in the cerrado.

\section{Final considerations}

Understood in this study that the agribusiness installation Uruçuí affected the increase in environmental problems such as deforestation, and the dispossession of family farming.

Furthermore, he highlighted that the dispossession of context confirmed, above all, the subordination of family labor to temporary work on farms, because it was, in particular, undervalued (with low-skilled and poorly paid); the reduction of mutual aid relationships (task forces) and dependence on chemical inputs.

Indeed, it is reiterated that the direct interference of agribusiness in the production practices of family Uruçuí farmers were demonstrating through the idyllic use of fertilizers or chemical fertilizers and pesticides, as well as in the allocation of machinery by lease or loan, with the purpose of performing land preparation and harvesting the crop.

Therefore, it was understood that, by necessity, family farmers combined their knowledge and cultural practices of the codes and references tecnoprodutivas of corporate agriculture. Soon, it expressed that due to the agro-industrial conjuncture Uruçuí, the livelihoods of family farmers have changed.

\section{Bibliographic references}

ALHO, C. J.; MARTINS, E. S. De grão em grão o cerrado perde espaço. (cerrado impactos do processo de ocupação). Brasília: WWF, 1995. (WWF - documento para discussão).

ALVES, V. E. L. As novas dinâmicas socioespaciais introduzidas pelo agronegócio nos cerrados da Bahia, Maranhão, Piauí e Tocantins. In: BERNARDES, J. A.; BRANDÃO FILHO, J. B. (Orgs.). A territorialidade do capital: geografias da soja II. Rio de Janeiro: Arquimedes Edições, 2009, pp. 151-175.

- Región centro-norte de Brasil: dinámicas territoriales recientes en el campo y en la ciudad. Cuadernos de Geografía, v. 23, n. 1. pp. 47-60, 2014.

ANDRADE, M. C. A terra e o homem no Nordeste: contribuição ao estudo da questão agrária no Nordeste. 8. ed. São Paulo: Cortez, 2011.

ARAÚJO, M. R. S.; ARAÚJO, J. L. L. A instituição dos cerrados piauienses como fronteira agrícola: o Estado e os capitais privados reorganizando espaços. In: LOPES, W. G. R. [et al] (Orgs.). Cerrado piauiense: uma visão multidisciplinar. Teresina: Edufpi, 2007, pp. 31-52.

BERNARDES, J. A. Fronteiras da agricultura moderna no cerrado Norte/Nordeste: descontinuidades e permanências. In: BERNARDES, J. A.; BRANDÃO FILHO, J. B. 
(Orgs.). A territorialidade do capital: geografias da soja II. Rio de Janeiro: Arquimedes Edições, 2009, pp. 13-39.

BRANDÃO FILHO, J. B. Dilemas e desafios da pequena produção agrícola frente à expansão do agronegócio no Piauí. In: BERNARDES, J. A; BRANDÃO FILHO, J. B. (Orgs.). A territorialidade do capital: geografias da soja II. Rio de Janeiro: Arquimedes Edições, 2009, pp. 115-136.

BRAZIL. Ministério do Meio Ambiente. PPCerrado: plano de ação para prevenção e controle do desmatamento e das queimadas no cerrado. 2. Fase (2014/2015). Brasília: MMA, 2014.

BROWDER, J. O.; PEDLOWSKI, M. A. \& WALKER, R. Revisiting theories of frontier expansion in the Brazilian Amazon: a survey of the colonist farming population in Rondônia's post-frontier, 1992-2002. World Development, v. 36, n. 8, pp. 1469-1492, 2008.

CANO, W. Desequilíbrios regionais e concentração industrial no Brasil, 1930-1995 . 2. ed. Campinas: Unicamp, 1998.

CHELOTTI, M. C. Reterritorialização e identidade territorial. Sociedade \& Natureza, v. 22, n. 1, pp. 165-180, 2010.

FUNDAÇÃO CENTRO DE PESQUISAS ECONÔMICAS E SOCIAIS DOPIAUÍ (CEPRO). Cerrados piauienses: estudo e análise de suas potencialidades, impactos da exploração da riqueza sobre a população da região. Teresina: Fundação CEPRO, 2014.

. Produto Interno Bruto Municipal do Piauí 2012. Teresina: Fundação CEPRO, 2015 .

FALEIRO, F. G.; GAMA, L. C.; FARIAS NETO, A. L.; SOUSA, E. S. O simpósio nacional sobre o cerrado e o simpósio internacional sobre savana tropical. In: FALEIRO, F. G.; FARIAS NETO, A. L. (Orgs.). Savanas: desafios e estratégias para o equilíbrio entre sociedade, agronegócio e recursos naturais. Planaltina: EMBRAPA Cerrados; Brasília: EMBRAPA Informação Tecnológica, 2008. pp. 33-46.

GRAZIANO DA SILVA, J. A nova dinâmica da agricultura brasileira. 2. ed. Campinas: Unicamp, 1998.

DELEUZE, G.; GUATTARI, F. Mil platôs: capitalismo e esquizofrenia 2.2 ed., v. 2, São Paulo: Editora 34, 2011.

INSTITUTO BRASILEIRO DE GEOGRAFIA E ESTATÍSTICA (IBGE). Censo demográfico 2010 (Piauí). Características da população e dos domicílios. Resultados do universo. Rio de Janeiro: IBGE, 2010. 
. Produção agrícola municipal no Piauí entre 1990 e 2018. (2020). Disponível em https://sidra.ibge.gov.br/pesquisa/pam/tabelas Acesso: 17 de abril de 2020.

INSTITUTO NACIONAL DE COLONIZAÇÃO E REFORMA AGRÁRIA (INCRA). Estrutura fundiária do Piauí por município. Teresina: INCRA (Superintendência regional do Piauí - SR 24), 2013, n/p.

MARTINS, J. S. Fronteira: a degradação do outro nos confins do humano. 2. ed. São Paulo: Contexto, 2014.

MATOS, P. F.; PESSÔA, V. L. S. A modernização da agricultura no Brasil e os novos usos do território. Geo UFRJ, v. 13, n. 22, pp. 290-322, 2011.

MONTEIRO, M. S. L.; AGUIAR, T. J. A. Ocupação do cerrado piauiense: valorização fundiária e consequências ambientais. In: ELIAS, D. S.; PEQUENO, R. (Orgs.). Difusão do agronegócio e novas dinâmicas socioespaciais. Fortaleza: Banco do Nordeste do Brasil, 2006, pp. 211-233.

MORAES, J. A.; MONTEIRO, M. S. L. O uso de agrotóxicos e as consequências para a saúde do trabalhador rural de Bom Jesus-PI. In: LOPES, W. G. R. [et al.]. Cerrado piauiense: uma visão multidisciplinar. Teresina: Edufpi, 2007, pp. 147-170.

MORAES, M. D. C. Um povo do cerrado entre baixões e chapadas: modo de vida e crise ecológica de camponeses(as) nos cerrados do sudoeste piauiense. In: GODOI, E. P.; MENEZES, M. A.; MARIN, R. A. (Orgs.). Diversidade do campesinato: expressões e categorias. v. 2 (estratégias de reprodução social). São Paulo: Unesp; Brasília: Núcleo de Estudos Agrários e Desenvolvimento Rural, 2009, pp. 131-161.

OLÍMPIO, J. A.; MONTEIRO, M. S. L. Impacto ambiental da produção de grãos no cerrado piauiense. In: LOPES, W. G. R. [et al.]. Cerrado piauiense: uma visão multidisciplinar. Teresina: Edufpi, 2007, pp. 97-122.

OLIVEIRA, A. U. Agricultura brasileira: transformações recentes. In: ROSS, J. L. S. (Org.). Geografia do Brasil. 5 ed. São Paulo: Edusp, 2005, pp. 465-534.

ORTEGA, A. C. Desarrollo territorial rural y estructuras de gobernanza en Brasil. Economía, Sociedad y Territorio, v. 12, n. 38, p. 149-179, 2012.

PEIXINHO, D. M.; SCOPEL, I. A territorialização da agricultura moderna no Piauí. In: BERNARDES, J. A.; BRANDÃO FILHO, J. B. (Orgs.). A territorialidade do capital: geografias da soja II (pp. 89-113). Rio de Janeiro: Arquimedes Edições, 2009.

PRADO JÚNIOR, C. História econômica do Brasil. São Paulo: Brasiliense, 2008.

SAHLINS, M. Sociedades tribais. Rio de Janeiro: Zahar Editores, 1983. 
SAUER, S. Agricultura familiar versus agronegócio: a dimensão sociopolítica do campo brasileiro. Texto para discussão n. 3, Brasília: Embrapa Informação Tecnológica, 2008.

SILVA, A. J. Agricultura familiar e a territorialização/desterritorialização/ reterritorialização provocada pelo agronegócio no cerrado piauiense: hibridismo sociocultural marginal em Uruçuí. 2016. 326 f. Tese (Doutorado em

Desenvolvimento e Meio Ambiente) - Universidade Federal do Piauí, Teresina, 2016.

SILVA, A. J.; ARAAÚJO, J. L. L.; BARROS, R. F. M. O desafio do babaçu (Orbignya speciosa Mart. Ex Spreng) no Piauí. Ra'ega - o espaço geográfico em análise, v. 33, p. 44-74, 2015.

SILVA, A. J.; MONTEIRO, M. S. L.; BARBOSA, E. L. Nova dinâmica produtiva e velhas questões territoriais nos cerrados setentrionais do Brasil. Revista Espacios, v. 36, n. 21, p. 14, $2015 a$.

. Difusão do agronegócio no Brasil: estratégias governamentais. Informe Econômico, v. 17, n. 34, p. 47-54, 2015 b.

. Agricultura familiar: perspectivas de um debate que esgota. CampoTerritório, v. 11, n. 24, pp. 70-98, 2016.

. Rugosidades da territorialização do capital na expansão da fronteira agrícola no sudoeste piauiense. In: QUIRÓS, R. R. (Org.). Tierra: naturaleza, biodiversidad y sustentabilidad. 1. ed. San José, Costa Rica: Jade, p. 860-869, $2017 a$.

. Territorialização da agricultura empresarial em Uruçuí/PI: de "espaço vazio" aos imperativos do agronegócio. Caderno de geografia, v. 27, número especial 1 , 2017b.

. A tradicionalidade do agricultor familiar do cerrado piauiense. Gaia Scientia, v. 11, n. 2, pp. 115-131, 2017c.

. Implicaciones sociales y ambientales del agronegocio em Uruçuí, Piauí, Brasil. Sociedade e Território, v. 29, n. 2, pp. 115-131, $2017 \mathrm{~d}$.

SILVA, A. J.; MONTEIRO, M. S. L.; SILVA, M. V. Contrapontos da consolidação do agronegócio no cerrado brasileiro. Sociedade e Território, v. 27, n. 3, p. 95-114, 2015.

SPOSITO, E. S. Geografia e filosofia: contribuição para o ensino do pensamento geográfico. São Paulo: Unesp, 2004.

WANDERLEY, M. N. B. Agricultura e campesinato: rupturas e continuidade. Estudos Sociedade e Agricultura, n. 21, p. 42-61, 2003.

WOLF, E. R. Sociedades camponesas. Rio de Janeiro: Zahar Editores, 1976. 
ZUQUIM, M. L. Os caminhos do rural: uma questão agrária e ambiental. São Paulo: Editora SENAC São Paulo, 2007.

Antonio Joaquim da Silva. Professor do DFPLC/IFPI - Campus Teresina Central. Instituto Federal de Educação, Ciência e Tecnologia do Piauí. antoniojoaquim@ifpi.edu.br

Maria do Socorro Lira Monteiro. Professora do Departamento de Ciências Econômicas/CCHL/UFPI. Universidade Federal do Piauí. socorrolira@uol.com.br

Eriosvaldo Lima Barbosa. Professor do Departamento de Planejamento e Política Agrícola/UFPI.eriosvaldobarbosa@hotmail.com

Como citar: SILVA, Antonio Joaquim da; MONTEIRO, Maria do Socorro Lira; BARBOSA, Eriosvaldo Lima. From modernization to deterritorialization: dynamics and dilemmas of agricultural work in the Cerrado of Piauí, Brazil. Redes (St. Cruz Sul, Online), Santa Cruz do Sul, v. 25, n. 2, p. 744-761, jan. 2020. ISSN 1982-6745. Disponível em: https://online.unisc.br/seer/index.php/redes/article/view/11678 Acesso em: 15 maio 2020. doi: https://doi.org/10.17058/redes.v25i2.11678

\section{CONTRIBUIÇÃO DE CADA AUTOR}

a. fundamentação teórico-conceitual e problematização: Antonio Joaquim da Silva

b. pesquisa de dados e análise estatística: Antonio Joaquim da Silva e Maria do Socorro Lira Monteiro

c. elaboração de figuras e tabelas: não se aplica

d. fotos: não se aplica

e. elaboração e redação do texto: Antonio Joaquim da Silva e Maria do Socorro Lira Monteiro

f. seleção das referências bibliográficas: Antonio Joaquim da Silva e Eriosvaldo Lima Barbosa

Fontes de financiamento: Coordenação de Aperfeiçoamento de Pessoal de Nível Superior. 